\title{
Elicitors on the control of anthracnose and post-harvest quality in papaya fruits ${ }^{1}$
}

\author{
Andréa Celina Ferreira Demartelaere ${ }^{2}$, Luciana Cordeiro do Nascimento ${ }^{2}$, \\ George Henrique Camêlo Guimarães ${ }^{2}$, Juliete Araújo da Silva ${ }^{2}$, Romulo Gil de Luna ${ }^{2}$
}

\begin{abstract}
Papaya is one of the most grown and consumed fruits in the world. However, post-harvest diseases are responsible for more than $50 \%$ of losses, including anthracnose, caused by Colletotrichum gloesporioides, which promotes necrotic and rounded lesions and reduces fruit quality. Alternative products have been widely investigated in the control of pathogens. This study aimed at evaluating the efficiency of elicitors in the control of anthracnose, as well as their effect on postharvest quality, in papaya fruits. The fruits were disinfested and immersed in acibenzolar-S-methyl, potassium phosphite, Rocksil $^{\circledR}$, Agro-mos $^{\circledR}$, Ecolife $^{\circledR}$, sterilized distilled water and prochloraz, inoculated with $C$. gloesporioides and stored. Potassium phosphite, Rocksil ${ }^{\circledR}$, Ecolife $^{\circledR}$ and prochloraz resulted in the smallest diameters of lesions, and, consequently, in a greater protection and enzymatic activity. The fruits treated with Rocksil $^{\circledR}$ and Ecolife ${ }^{\circledR}$ maintained the lowest levels of soluble solids and titratable acidity. Potassium phosphite, Rocksil ${ }^{\circledR}$ and Ecolife ${ }^{\circledR}$ are effective in controlling anthracnose, do not change the appearance and preserve the post-harvest quality of papaya fruits, and, therefore, may be used as an alternative to commercial fungicides.
\end{abstract}

KEYWORDS: Carica papaya L.; Colletotrichum gloesporioides; fungicide.

\section{INTRODUCTION}

Papaya (Carica papaya L.) is one of the most widely grown and consumed fruits in tropical and subtropical regions of the world, due to its pleasant aroma and taste, as well as high nutritional value (rich in calcium, magnesium, potassium, vitamins $\mathrm{C}$ and E) (Viana et al. 2015).

Papaya is an economically important crop in Brazil, with a production of 1.50 million tons in 2016 (CNA 2017), becoming the third most widely consumed fruit in the country. Therefore, papaya has a considerable nutritional and social importance in

\section{RESUMO}

Elicitores no controle de antracnose e qualidade pós-colheita em frutos de mamoeiro

O mamão é uma das frutas mais cultivadas e consumidas no mundo. Entretanto, as doenças pós-colheita são responsáveis por mais de $50 \%$ de perdas, dentre elas a antracnose, causada por Colletotrichum gloesporioides, que promove lesões necróticas e arredondadas e reduz a qualidade dos frutos. Produtos alternativos têm sido amplamente investigados no controle de patógenos. Objetivou-se avaliar a eficiência de elicitores no controle de antracnose e seu efeito na qualidade pós-colheita, em frutos de mamoeiro. Os frutos foram desinfestados e imersos em acibenzolarS-methyl, fosfito de potássio, Rocksil ${ }^{\circledR}$, Agro-mos $^{\circledR}$, Ecolife $^{\circledR}$, água destilada esterilizada e prochloraz, inoculados com $C$. gloesporioides e armazenados. Fosfito de potássio, Rocksil ${ }^{\circledR}$, Ecolife $^{\circledR}$ e prochloraz resultaram nos menores diâmetros das lesões e, consequentemente, em maior proteção e atividade enzimática. Os frutos tratados com Rocksil $^{\circledR}$ e Ecolife ${ }^{\circledR}$ mantiveram os menores teores de sólidos solúveis e acidez titulável. Fosfito de potássio, Rocksil ${ }^{\circledR}$ e Ecolife ${ }^{\circledR}$ são eficazes no controle de antracnose, não alteram a aparência e preservam a qualidade pós-colheita de frutos de mamoeiro e, consequentemente, podem ser uma alternativa aos fungicidas comerciais.

PALAVRAS-CHAVE: Carica papaya L.; Colletotrichum gloesporioides; fungicida.

the generation of employment and income (Galo et al. 2014). Papaya stands out as the third most produced fruit in the Northeast region and the fourth in terms of national production (Costa et al. 2011). Despite the high production, post-harvest losses can be caused by mechanical and physiological damages, and mainly by pathogens, affecting the development of crops and the Brazilian regional economy (Ruggiero et al. 2011).

Post-harvest diseases are responsible for losses, in many cases, of more than $50 \%$ in fruits, before they are available to consumers, and those that are available do not always have the desired quality.

1. Manuscript received in Jan./2017 and accepted for publication in Jun./2017 (http://dx.doi.org/10.1590/1983-40632016v4745093).

2. Universidade Federal da Paraíba, Centro de Ciências Agrárias, Areia, PB, Brazil.E-mails: andrea_celina@hotmail.com, luciana.cordeiro@cca.ufpb.br, guimaraesghc@hotmail.com, jullyetearaujo@hotmail.com, romulo.luna@ig.com.br. 
Anthracnose, caused by the Colletotrichum gloeosporioides fungus, presents symptoms that usually appear with the ripening of the fruit, being characterized by the presence of large, necrotic and rounded lesions, which can reach different diameters and where masses of salmon coloring conidia emerge (Nascimento et al. 2010).

The control of this disease is often made through the application of agrochemicals, especially fungicides. However, the increased resistance of phytopathogens, as well as the evidence of the harmful effects of these products to the environment and human health, has led to a growing demand for new control alternatives (Kefialewa \& Avalewb 2008). In this respect, natural products have been extensively investigated, because they present no toxicity to humans and animals and may improve the physiological characteristics of vegetables, as well as their capacity of activating defense mechanisms (Stangarlin et al. 2011).

The alternative control using natural products, such as elicitors, may stimulate the production of peroxidase, polyphenol oxidase and phenylalanine ammonia-lyase enzymes, which produce secondary metabolites that induce resistance (indirect mechanism), as well as the formation of different phenolic compounds that are toxic to fungi (direct mechanism) (Bonett et al. 2012).

Several researchers have studied the effect of elicitors to control anthracnose. Ribeiro et al. (2016) used Rocksil ${ }^{\circledR}$ at concentrations of $15 \mathrm{~g} \mathrm{~L}^{-1}$ and $30 \mathrm{~g} \mathrm{~L}^{-1}$ and observed inhibition of C. gloesporioides in papaya fruits. Lopes (2008) evaluated potassium phosphite and observed reductions in the lesions caused by C. gloeosporioides. Dantas et al. (2003), using Agromos ${ }^{\circledR}$ in papaya fruits, also verified a significant reduction in the $C$. gloeosporioides incidence, favoring the anthracnose reduction.

Researches in the area of post-harvest diseases in fruits aim to clarify the mechanisms of the pathogen attack, symptoms in the fruits and metabolic alterations that compromise the final quality, as well as the control methods. Although the chemical control is one of the most efficient methods, it has been quite restricted, by leaving toxic residues in the fruits and contaminating people (Fischer et al. 2012).

The use of alternative products such as elicitors in the control of anthracnose in papaya fruits has been very promising, because they have a high fungitoxic potential (direct mechanism) and activate the enzymes (indirect mechanism) that influence the induction of resistance (Stangarlin et al. 2011). Besides, these alternative products may provide high quality fruits and extend the storage time, without altering the physical, chemical and sensory characteristics that are preferred by consumers.

Few research articles have evaluated the use of elicitors as an alternative to control anthracnose in papaya fruits by inducing resistance and proving, through enzymatic activity, that it is possible to keep the fruit appearance and quality. Thus, the present study aimed at evaluating the effectiveness of elicitors in the control of anthracnose and their influence on the post-harvest quality of papaya fruits.

\section{MATERIAL AND METHODS}

The experiment was conducted at the Universidade Federal da Paraíba, in Areia, Paraíba state, Brazil, from September to December 2016.

A completely randomized experimental design, with 7 treatments (acibenzolar-S-methyl, potassium phosphite, Rocksil ${ }^{\circledR}$, Agro-mos $^{\circledR}$, Ecolife $^{\circledR}$, sterilized distilled water and prochloraz), was used. Five repetitions of each treatment were performed with five papaya fruits.

Papaya fruits ('Sunrise Solo' cultivar) were collected at the maturity stage 1 , with a completely green skin (Ceagesp 2000), from a commercial orchard in Areia (06 $57^{\circ} 48^{\prime \prime} \mathrm{S}$ and $35^{\circ} 41^{\prime} 30^{\prime \prime} \mathrm{W}$ ). Fruits were then transported to the laboratory, disinfested with a $1 \%$ solution of sodium hypochlorite for $3 \mathrm{~min}$ and rinsed three times with sterilized distilled water.

After drying, the papaya fruits were immersed, for $5 \mathrm{~min}$, in either $0.2 \mathrm{~g} \mathrm{~L}^{-1}$ of acibenzolar-Smethyl, $150 \mathrm{~mL} \mathrm{ha}^{-1}$ of potassium phosphite $\left(\mathrm{P}_{2} \mathrm{O}_{5} 40 \%+\mathrm{K} 20 \%\right.$ - product originated from the neutralization of phosphorus acid by a base), $30 \mathrm{~g} \mathrm{~L}^{-1}$ of Rocksil ${ }^{\circledR}$ (mineral earth compound rich in aluminum oxide, silicon dioxide, sulfur and other chemical compounds), $50 \mathrm{~mL} / 20 \mathrm{~L}$ of Agro-mos ${ }^{\circledR}$ (phosphorylated mannan-oligosaccharide-based product rich in nutrients, amino acids and vitamins) or $3 \mathrm{~mL} \mathrm{~L}^{-1}$ of Ecolife ${ }^{\circledR}$ (product composed of bioflavonoids), depending on the treatment. The negative control was sterilized distilled water and the positive control was the commercial fungicide prochloraz $\left(450 \mathrm{~g} \mathrm{~L}^{-1}\right)$. After drying, the papaya fruits 
were placed on polypropylene trays and stored for 12 days, at $23 \pm 2{ }^{\circ} \mathrm{C}$ and $70 \%$ of relative humidity.

A C. gloesporioides isolate was collected from papaya fruits with typical symptoms of anthracnose acquired from local commercial establishments and cultivated in potato dextrose agar medium at $27 \pm 2{ }^{\circ} \mathrm{C}$, under a 12-h light/dark photoperiod, for 7 days. With the aid of an optical microscope (400X), it was possible to observe that colonies varied between colorless and pale brown, with orange conidial mass. Conidia were hyaline, aseptate, cylindrical with round ends, slightly flattened, smooth-walled, guttulate and with $13.5(10.5-17.1) \mu \mathrm{m} \times 3.8(2.1-4.8) \mu \mathrm{m}$, as described by Sutton (1992).

After the morphological analysis and $24 \mathrm{~h}$ of the elicitors application, $10 \mathrm{~mL}$ of sterilized distilled water were placed in Petri dishes with the fungal culture, which was agitated with a soft-bristle brush. The fungal mass was filtered with gauze and the number of conidia was counted in a Neubauer chamber. Five wounds were applied to the fruits, using a metal needle $\mathrm{n}^{\circ} 6$, and, with a pipette, $15 \mu \mathrm{L}$ of the suspension inoculated with $1.0 \times 10^{5}$ conidia $\mathrm{mL}^{-1}$ of $C$. gloeosporioides were inoculated at three opposite points, in the equatorial region of the fruit (Gomes 2008). From the second day after inoculation, the lesion diameter in the fruits was measured with a millimeter ruler.

Starting from the second day after inoculation, daily evaluations of severity were performed, using the diagrammatic scale described by Nery-Silva et al. (2001). The area under the disease progress curve (AUDPC) was calculated in millimeters: AUDPC $=\Sigma\left[\left(\mathrm{y}_{1}+\mathrm{y}_{2}\right) / 2 *\left(\mathrm{t}_{2}-\mathrm{t}_{1}\right)\right]$, in which $y_{1}$ and $y_{2}$ are the percentages of area affected on the papaya fruits and $t_{2}-t_{1}$ the intervals between evaluations (Shaner \& Finney 1977). The papaya fruits protection was calculated based on the AUDPC of each treatment: $\%$ of protection $=($ AUDPC of treatment $x$ 100/ AUDPC of control).

At the end of 12 days of storage, the phenylalanine ammonia-lyase activity was determined based on the quantification of trans-cinnamic acid (Umesha 2006). Peroxidase and polyphenoloxidase activities were determined using the methods described by Roncato \& Pascholati (1998). All assays were conducted in triplicate and the results expressed as UA $\mathrm{min}^{-1} \mathrm{mg}^{-1}$ of protein.

Quality parameters were evaluated following Demartelaere et al. (2015). The content of soluble solids (SS) was determined in juice extracted from slices of papaya fruits cut longitudinally. For such, a digital refractometer with automatic temperature correction was used and the results were expressed as percentage values. Titratable acidity (TA) was determined using sodium hydroxide $0.1 \mathrm{~N}$ and expressed as percentage of citric acid/100 g of juice. The SS/TA ratio was determined by dividing SS by TA. Hydrogen potential $(\mathrm{pH})$ was determined using a digital potentiometer with automatic temperature correction. The weight loss was determined daily with a semi-analytical scale, using the initial weight as the baseline value. The external appearance of the papaya fruits was evaluated using a scale ranging from 1 to 5 (papaya fruits with scores equal to or less than 3 were considered unsuitable for consumption). The skin color was determined using the subjective scale proposed by Wills \& Widjanarko (1995), with modifications.

The average fungal incidence, AUDPC, protection, peroxidase, polyphenoloxidase and phenylalanine ammonia-lyase activities and postharvest quality (SS, TA, SS/TA ratio, $\mathrm{pH}$, appearance and skin color) were evaluated using analysis of variance ( $F$ test). The Tukey test was used for average comparison $(\mathrm{p}<0.01)$. All analyses were performed using the Sisvar ${ }^{\circledR}$ software (Ferreira 2008).

\section{RESULTS AND DISCUSSION}

Potassium phosphite, Rocksil ${ }^{\circledR}$, Ecolife ${ }^{\circledR}$ and the positive control prochloraz led to the smallest lesion diameters $(11.50 \mathrm{~mm}, 12.60 \mathrm{~mm}, 13.50 \mathrm{~mm}$ and $8.10 \mathrm{~mm}$, respectively), the lowest AUDPC of the disease progression $(1.17,1.30,1.47$ and 1.15 , respectively) and the highest protection percentages $(82.25 \%, 79.15 \%, 77.65 \%$ and $84.65 \%$, respectively) (Table 1$)$. The results showed that these products were efficient in reducing the symptoms of anthracnose in papaya fruits at 12 days of storage. This can be explained due to the fact that the use of elicitors of abiotic origin leads the fruit to react, producing a series of responses that block the infection of the pathogen. For example, the potassium phosphite activates defense mechanisms, promoting a series of biochemical and physiological alterations that increase the production of PRs-proteins, signaling compounds (salicylic acid) phytoalexins, as well as the accumulation of reactive oxygen species (Junqueira 2010). 
Among the effective elicitors, Rocksil ${ }^{\circledR}$ contains silicon, which is an element that increases the resistance of plants to the attack of pathogens. Recent studies have suggested that, besides the mechanical effect on the penetration of the spores of the pathogen into the host, $\mathrm{Si}$ is also involved with the accumulation of antifungal compounds, by activating defense-related enzymes and phytoalexins (Ribeiro et al. 2016).

Ecolife $^{\circledR}$ is composed of bioflavonoids, ascorbic acid and citric phytoalexins, exerting a protective/curative effect on fruits, due to the synergic action of its components. It also regulates plant growth, leading to the direction of greater energy to the reproductive needs of plants (Furtado et al. 2010).

In addition to the promising results obtained in the present study, other researches also recorded positive effects. Ribeiro et al. (2016), for example, used Rocksil $^{\circledR}$ at a concentration of $30 \mathrm{~g} \mathrm{~L}^{-1}$ and found lower severity of anthracnose on papaya, in comparison to the other treatments tested. Applying Ecolife $^{\circledR}$ for the control of anthracnose on papaya,
Carnelossi et al. (2009) found lesions measuring $1.0 \mathrm{~mm}$ in length, as well as a lower AUDPC, in comparison to the other treatments tested. However, the present findings demonstrate that elicitors are promising agents for the control of diseases in tropical fruits (Guimarães et al. 2017). These alternative products do not harm the environment, do not lead to the accumulation of toxic residues on fruits and induce the activation of defense mechanisms (Demartelaere et al. 2015).

Acibenzolar-S-methyl and Agro-mos ${ }^{\circledR}$ demonstrated ineffective results for the control of anthracnose in the present study. However, Gomes et al. (2009) state that the efficacy of these products and other alternative control measures varies across species and varieties, due to the biochemical characteristics of the fruit tissue, pathogen, host, elicitor concentration, form of application and defense responses.

Differences among the enzymes were found, regarding peroxidase, polyphenoloxidase and phenylalanine ammonia-lyase (Table 2). Potassium

Table 1. Lesion diameter, area under the disease progression curve (AUDPC) and protection in papaya fruits (Carica papaya L.) treated with elicitors, at 12 days of storage, under $23 \pm 2{ }^{\circ} \mathrm{C}$ and relative humidity of $70 \%$.

\begin{tabular}{|c|c|c|c|}
\hline \multirow{2}{*}{ Elicitor } & Lesion diameter & \multirow{2}{*}{ AUDPC } & \multirow{2}{*}{$\begin{array}{c}\text { Protection } \\
\%\end{array}$} \\
\hline & $\mathrm{mm}$ & & \\
\hline Acibenzolar-S-methyl $\left(0.2 \mathrm{~g} \mathrm{~L}^{-1}\right)$ & $56.75 b^{*}$ & $6.00 \mathrm{a}$ & $4.76 \mathrm{c}$ \\
\hline Potassium phosphite (150 mL ha-1) & $11.50 \mathrm{~d}$ & $1.17 \mathrm{~b}$ & $82.25 \mathrm{a}$ \\
\hline $\operatorname{Rocksil}^{\circledR}\left(30 \mathrm{~g} \mathrm{~L}^{-1}\right)$ & $12.60 \mathrm{~d}$ & $1.30 \mathrm{~b}$ & $79.15 \mathrm{a}$ \\
\hline $\operatorname{Agro}-m o s^{\circledR}(50 \mathrm{~mL} / 20 \mathrm{~L})$ & $39.00 \mathrm{c}$ & $5.85 \mathrm{a}$ & $7.97 \mathrm{~b}$ \\
\hline Ecolife $^{\circledR}\left(3 \mathrm{~mL} \mathrm{~L}^{-1}\right)$ & $13.50 \mathrm{~d}$ & $1.47 \mathrm{~b}$ & $77.65 \mathrm{a}$ \\
\hline Sterilized distilled water $\left(450 \mathrm{~g} \mathrm{~L}^{-1}\right)$ & $73.40 \mathrm{a}$ & $6.37 \mathrm{a}$ & $0.00 \mathrm{~d}$ \\
\hline Prochloraz $\left(450 \mathrm{~g} \mathrm{~L}^{-1}\right)$ & $8.10 \mathrm{~d}$ & $1.15 \mathrm{~b}$ & $84.65 \mathrm{a}$ \\
\hline $\mathrm{CV}(\%)$ & 18.40 & 13.36 & 9.18 \\
\hline
\end{tabular}

* Means followed by the same lowercase letter in the row do not differ by the Tukey test $(\mathrm{p}<0.01)$.

Table 2. Enzymatic activity of peroxidase, polyphenoloxidase and phenylalanine ammonium-lyase in papaya fruits (Carica papaya L.) treated with elicitors, at 12 days of storage, under $23 \pm 2{ }^{\circ} \mathrm{C}$ and relative humidity of $70 \%$.

\begin{tabular}{|c|c|c|c|}
\hline \multirow{2}{*}{ Elicitor } & Peroxidase & Polyphenoloxidase & phenylalanine ammonium-lyase \\
\hline & \multicolumn{3}{|c|}{ UA min $^{-1} \mathrm{mg}^{-1}$ of protein } \\
\hline Acibenzolar-S-methyl $\left(0.2 \mathrm{~g} \mathrm{~L}^{-1}\right)$ & $97.15 b^{*}$ & $3.00 \mathrm{c}$ & $4.15 \mathrm{~b}$ \\
\hline Potassium phosphite $\left(150 \mathrm{~mL} \mathrm{ha}^{-1}\right)$ & $278.15 \mathrm{a}$ & $8.77 \mathrm{a}$ & $9.22 \mathrm{a}$ \\
\hline $\operatorname{Rocksil}^{\circledR}\left(30 \mathrm{~g} \mathrm{~L}^{-1}\right)$ & $285.00 \mathrm{a}$ & $8.77 \mathrm{a}$ & $9.57 \mathrm{a}$ \\
\hline${\operatorname{Agro}-\operatorname{mos}^{\circledR}}^{\circledR}(50 \mathrm{~mL} / 20 \mathrm{~L})$ & $90.92 \mathrm{~b}$ & $3.17 \mathrm{c}$ & $3.97 \mathrm{~b}$ \\
\hline $\operatorname{Ecolife}^{\mathbb{B}}\left(3 \mathrm{~mL} \mathrm{~L}^{-1}\right)$ & $290.25 \mathrm{a}$ & $8.89 \mathrm{a}$ & $9.90 \mathrm{a}$ \\
\hline Sterilized distilled water $\left(450 \mathrm{~g} \mathrm{~L}^{-1}\right)$ & $86.85 \mathrm{~b}$ & $4.50 \mathrm{~b}$ & $3.52 \mathrm{~b}$ \\
\hline Prochloraz $\left(450 \mathrm{~g} \mathrm{~L}^{-1}\right)$ & $261.25 \mathrm{a}$ & $8.86 \mathrm{a}$ & $9.66 \mathrm{a}$ \\
\hline CV $(\%)$ & 11.77 & 9.91 & 13.42 \\
\hline
\end{tabular}


phosphite, Rocksil ${ }^{\circledR}$ and prochloraz reached significantly greater enzyme activities, in comparison to the other treatments, at 12 days of storage (Table 2).

A similar behavior was reported in previous studies. Demartelaere et al. (2015) used Allamanda blanchetti extract as an elicitor on papaya fruits and found a reduction in the severity of anthracnose, as well as a high peroxidase activity. Alamino et al. (2013) used elicitors for the control of anthracnose on apples ('Royal Gala' cultivar) and found an increase in the peroxidase activity, as well as reductions in the affected area of the fruit and sporulation of C. gloeosporioides. Borsatti et al. (2015) used elicitors on post-harvest blackberries (Rubus spp.) and observed an increase in phenylalanine ammonialyase, as well as a lower incidence of fruit rot.

The high activity of these enzymes is a strong indicator that the elicitors are responsible for the activation of defense genes in fruits. Peroxidase, polyphenoloxidase and phenylalanine ammoniumlyase can be activated by biotic (viable microorganisms) or abiotic (elicitors) factors, which induce defense responses, involving biochemical and structural mechanisms. This induction can trigger a series of events, such as oxidative outbursts, hypersensitivity responses, accumulation of pathogenesis-related proteins such as chitinases and $\beta-1,3$-glucanases, enzymes involved in the route of phenylpropanoids as phenylalanine ammonia lyase and others such as polyphenoloxidase and peroxidase, and the synthesis of phytoalexins (Stangarlin et al. 2011).

According to Bezerra et al. (2011), the expression of peroxidase and polyphenoloxidase is related to different physiological functions, as well as stress and the biosynthesis of lignin, which act on cells whose neighbor cells have been infected and/or damaged. This process is called reaction of hypersensitivity, which is a direct defense mechanism in the area of the fruit affected by pathogens. Phenylalanine ammonia-lyase is one of the key enzymes of the phenylpropanoid pathway, responsible for the deamination of L-phenylalanine, with the consequent formation of trans-cinnamic acid. This secondary metabolite is a phenolic compound with fungitoxic action and is produced constitutively in fruits as a response to attacks from pathogens (Almeida et al. 2012).

Fruits treated with Rocksil ${ }^{\circledR}$ and Ecolife ${ }^{\circledR}$ had the lowest content of soluble solids $(9.70 \%$ and $9.57 \%$, respectively, in comparison with $11.07 \%$ in untreated papaya fruits) and the lowest titrable acidity. All the other elicitors did not affect soluble solids and acidity, in comparison to untreated fruits. No statistical difference was observed for $\mathrm{pH}$ among the treatments (Table 3). This indicates that these elicitors may not cause alterations in the quality of post-harvest papaya fruits, since sugars are the primary source used by fruit metabolism for the production of energy and are influenced by factors such as storage time and temperature. Indeed, high temperatures favor higher metabolic rates, and the increase in soluble solids during storage is common (Costa et al. 2010). Fruits treated with elicitors have lower levels of reducing and total sugars, what indicates a delay in ripening (Guimarães et al. 2017).

The weight loss accumulated over 12 days of storage was the highest among untreated papaya fruits $(14.11 \%)$ and the lowest among those treated with Ecolife ${ }^{\circledR}(9.45 \%)$ (Table 4). The weight loss may be explained by metabolic processes, which are common during storage, as fruits continue to transpire and lose water by vapor. The weight loss

Table 3. Soluble solids (SS), titratable acidity (TA), SS/TA ratio and $\mathrm{pH}$ in papaya fruits (Carica papaya L.) treated with elicitors, at 12 days of storage, under $23 \pm 2{ }^{\circ} \mathrm{C}$ and relative humidity of $70 \%$.

\begin{tabular}{|c|c|c|c|c|}
\hline \multirow{2}{*}{ Elicitor } & Soluble solids (SS) & Titrable acidity (TA) & \multirow{2}{*}{$\mathrm{SS} / \mathrm{TA}$ ratio } & \multirow{2}{*}{$\mathrm{pH}$} \\
\hline & $\%$ & ${\mathrm{~g} 100 \mathrm{~g}^{-1}}$ & & \\
\hline Acibenzolar-S-methyl $\left(0.2 \mathrm{~g} \mathrm{~L}^{-1}\right)$ & $10.50 \mathrm{ab}^{*}$ & $0.10 \mathrm{~b}$ & $104.00 \mathrm{ab}$ & $5.52 \mathrm{a}$ \\
\hline Potassium phosphite $\left(150 \mathrm{~mL} \mathrm{ha}^{-1}\right)$ & $10.69 \mathrm{ab}$ & $0.11 \mathrm{ab}$ & $100.26 \mathrm{ab}$ & $5.07 \mathrm{a}$ \\
\hline $\operatorname{Rocksil}^{\circledR}\left(30 \mathrm{~g} \mathrm{~L}^{-1}\right)$ & $9.70 \mathrm{~b}$ & $0.13 \mathrm{a}$ & $74.81 \mathrm{~b}$ & $5.45 \mathrm{a}$ \\
\hline Agro-mos ${ }^{\circledR}(50 \mathrm{~mL} / 20 \mathrm{~L})$ & $10.40 \mathrm{ab}$ & $0.09 \mathrm{~b}$ & $119.04 \mathrm{a}$ & $5.45 \mathrm{a}$ \\
\hline Ecolife $^{\circledR}\left(3 \mathrm{~mL} \mathrm{~L}^{-1}\right)$ & $9.57 \mathrm{~b}$ & $0.14 \mathrm{a}$ & $69.58 \mathrm{~b}$ & $5.51 \mathrm{a}$ \\
\hline Sterilized distilled water $\left(450 \mathrm{~g} \mathrm{~L}^{-1}\right)$ & $11.07 \mathrm{a}$ & $0.10 \mathrm{~b}$ & $119.79 \mathrm{a}$ & $5.36 \mathrm{a}$ \\
\hline Prochloraz $\left(450 \mathrm{~g} \mathrm{~L}^{-1}\right)$ & $10.23 \mathrm{ab}$ & $0.10 \mathrm{~b}$ & $100.49 \mathrm{ab}$ & $5.55 \mathrm{a}$ \\
\hline $\mathrm{CV}(\%)$ & 4.17 & 11.57 & 16.48 & 3.9 \\
\hline
\end{tabular}

* Means followed by the same letter in the rows do not differ significantly by the Tukey test $(\mathrm{p}<0.01)$. 
Table 4. Weight loss, color (1-6) and appearance (1-5) in papaya fruits (Carica papaya L.) treated with plant elicitors, at 12 days of storage, under $23 \pm 2{ }^{\circ} \mathrm{C}$ and relative humidity of $70 \%$.

\begin{tabular}{lccc}
\hline \multicolumn{1}{c}{ Elicitor } & Weight loss $(\%)$ & Skin color & Appearance \\
\hline Acibenzolar-S-methyl $\left(0.2 \mathrm{~g} \mathrm{~L}^{-1}\right)$ & $10.78 \mathrm{ab}^{*}$ & $5.85 \mathrm{a}$ & $2.70 \mathrm{ab}$ \\
Potassium phosphite $\left(150 \mathrm{~mL} \mathrm{ha}^{-1}\right)$ & $14.72 \mathrm{a}$ & $5.75 \mathrm{a}$ & $2.45 \mathrm{ab}$ \\
Rocksil $^{\circledR}\left(30 \mathrm{~g} \mathrm{~L}^{-1}\right)$ & $12.73 \mathrm{ab}$ & $5.65 \mathrm{ab}$ & $3.00 \mathrm{a}$ \\
Agro-mos $^{\circledR}(50 \mathrm{~mL} / 20 \mathrm{~L})$ & $11.03 \mathrm{ab}$ & $5.85 \mathrm{a}$ & $2.00 \mathrm{~b}$ \\
Ecolife $^{\circledR}\left(3 \mathrm{~mL} \mathrm{~L}^{-1}\right)$ & $9.45 \mathrm{~b}$ & $5.00 \mathrm{~b}$ & $3.10 \mathrm{a}$ \\
${\text { Sterilized distilled water }\left(450 \mathrm{~g} \mathrm{~L}^{-1}\right)}_{\text {Prochloraz }\left(450 \mathrm{~g} \mathrm{~L}^{-1}\right)}^{14.11 \mathrm{a}}$ & $5.85 \mathrm{a}$ & $1.75 \mathrm{~b}$ \\
\hline $\mathrm{CV}(\%)$ & $10.58 \mathrm{ab}$ & $5.95 \mathrm{a}$ & $3.25 \mathrm{a}$ \\
\hline
\end{tabular}

* Means followed by the same letter in the rows do not differ significantly by the Tukey test $(\mathrm{p}<0.01)$. Scales: color $(1$ : totally green; 6 : totally yellow) and appearance (1: unacceptable; 3: regular; 5: excellent).

in tropical fruits is partially caused by the loss of turgidity in vegetal tissues, which is associated with an increase in membrane permeability, leading to a high loss of water.

Researchers consider the critical limit of weight loss to be $10 \%$, with higher percentages affecting the visual characteristics of fruits (Demartelaere et al. 2015). The limit of acceptance for fruit, on an appearance scale, is 3 (slight loss of turgidity, absence of disease and little shine). The use of prochloraz resulted in the highest appearance score (3.25), but this value did not differ significantly from Ecolife ${ }^{\circledR}$ (3.10) or Rocksil ${ }^{\circledR}$ (3.00) (Table 4). The green skin color may indicate a delay on maturation. Fruits treated with Ecolife ${ }^{\circledR}$ had the lowest skin color scores (5.00) (Table 4).

\section{CONCLUSION}

The potassium phosphite, Rocksil $^{\circledR}$ and Ecolife ${ }^{\circledR}$ elicitors are effective in controlling anthracnose, do not change the appearance and preserve the post-harvest quality of papaya fruits, and, therefore, may be an alternative to commercial fungicides.

\section{REFERENCES}

ALAMINO, A. A. et al. Indução de resistência à podridão-amarga em maçãs pelo uso de eliciadores em pós-colheita. Pesquisa Agropecuária Brasileira, v. 48, n. 3, p. 249-254, 2013.

ALMEIDA, H. O. et al. Enzimas marcadoras de indução de resistência diferencialmente reguladas em soja resistente e suscetível à ferrugem-asiática-da-soja. Pesquisa Agropecuária Brasileira, v. 47, n. 2, p. 163172, 2012.
BEZERRA, D. A. C. et al. Abordagem fitoquímica, composição bromatológica e atividade antibacteriana de Mimosa tenuiflora (Wild) Poiret e Piptadenia stipulacea (Benth) Ducke. Acta Scientiarum, v. 33, n. 1, p. 99-106, 2011.

BONETT, L. P. et al. Extrato etanólico de representantes de cinco famílias de plantas e óleo essencial da família Asteraceae sobre o fungo Colletotrichum gloeosporioides coletados de frutos de mamoeiro (Carica papaya L.). Revista Brasileira de Agroecologia, v. 7, n. 3, p. 116-125, 2012.

BORSATTI, F. C. et al. Indução de resistência e qualidade pós-colheita de amora-preta tratada com ácido salicílico. Revista Brasileira de Fruticultura, v. 37, n. 2, p. 318-326, 2015.

CARNELOSSI, P. R. et al. Óleos essenciais no controle pós-colheita de Colletotrichum gloeosporioides em mamão. Revista Brasileira de Plantas Medicinais, v. 11, n. 4, p. 399-406, 2009.

COMPANHIA DE ENTREPOSTOS E ARMAZÉNS GERAIS DE SÃO PAULO (Ceagesp). Programa brasileiro para a melhoria dos padrões comerciais e embalagens de hortigrangeiros: classificação das tangerinas. 2000. Available at: $<$ https://www.bdpa.cnptia. embrapa.br/busca? $\mathrm{b}=\mathrm{ad} \&$ biblioteca $=$ vazio\&busca $=$ autori a:\%22CEAGESP.\%22>. Access on: 15 Dec., 2015.

CONFEDERAÇÃO NACIONAL DE AGRICULTURA E PECUÁRIA DO BRASIL (CNA). O municipio de Linhares, no Espírito Santo, é modelo na produção de mamão no País. 2017. Available at: <http://www.cnabrasil. org.br/noticias/o-municipio-de-linhares-no-espirito-santoe-modelo-na-producao-de-mamao-no-pais $>$. Access on: 10 Jul., 2017.

COSTA, F. B. et al. Armazenamento refrigerado do mamão Havaí 'Golden' produzido na Chapada do Apodi - RN Brasil. Revista Verde, v. 5, n. 4, p. 37-54, 2010. 
COSTA, L. C. et al. Procedência, qualidade e perdas pós-colheita de mamão 'Havaí' no mercado atacadista da Empasa de Campina Grande - PB. Agropecuária Técnica, v. 32, n. 1, p. 21-34, 2011.

DANTAS, S. A. F. et al. Doenças fúngicas pós-colheita em mamões e laranjas comercializados na Central de Abastecimento do Recife. Fitopatologia Brasileira, v. 28, n. 5, p. 528-533, 2003.

DEMARTELAERE, A. C. F. et al. Extratos vegetais no controle da antracnose e na conservação da qualidade em frutos de mamoeiro. Revista Brasileira de Plantas Medicinais, v. 17, n. 4, p. 1041-1048, 2015.

FERREIRA, D. F. Sisvar: um programa para análises e ensino de estatística. Revista Symposium, v. 6, n. 1, p. 36$41,2008$.

FISCHER, I. H. et al. Efeito de fungicidas e produtos alternativos no controle da antracnose e da pinta preta da goiaba. Semina: Ciências Agrárias, v. 33, suppl., p. 27532766, 2012.

FURTADO, L. M. et al. Utilização de Ecolife $^{\circledR}$ e Acibenzolar-s-metil (ASM) no controle da antracnose da banana em pós-colheita. Summa Phytopathologica, v. 36, n. 3, p. 237-239, 2010.

GALO, J. de Q. B. et al. Conservação pós-colheita de mamão 'Sunrise solo' com uso de quitosana. Revista Brasileira de Fruticultura, v. 36, n. 2, p. 305-312, 2014.

GOMES, E. C. S.; PEREZ, J. O.; BARBOSA, J. Resistência induzida como componente do manejo de doenças da videira. Engenharia Ambiental, v. 6, n. 2, p. 114-120, 2009.

GOMES, L. I. S. Métodos de inoculação de Colletotrichum gloesporioides e efeito de óleos essenciais no controle da antracnose em frutos de mamoeiro. 2008. 53 f. Dissertação (Mestrado em Agronomia) - Universidade Federal de Lavras, Lavras, 2008.

GUIMARÃES, G. H. C. et al. Impact of cassava starchalginate based coatings added with ascorbic acid and elicitor on quality and sensory attributes during pineapple storage. African Journal of Agricultural Research, v. 12, n. 9, p. 664-673, 2017.

JUNQUEIRA, K. P. Resistência genética e métodos alternativos de controle da bacteriose do maracujazeiro causada por Xanthomonas axonopodis pv. passiflorae. 2010. 172 f. Tese (Doutorado em Fitopatologia) Universidade de Brasília, Brasília, DF, 2010.

KEFIALEWA, Y.; AVALEWB, A. Post-harvest biological control of anthracnose (Colletotrichum gloeosporioides) on mango (Mangifera indica). Post-harvest Biology and Technology, v. 50, n. 1, p. 8-10, 2008.

LOPES, L. F. Efeitos de aplicações pós-colheita de fosfitos, ácido acetilsalicílico e 1-metilciclopropeno sobre a antracnose do mamoeiro. 2008. 82 f. Dissertação (Mestrado em Fitopatologia) - Universidade de Brasília, Brasília, DF, 2008.

NASCIMENTO, R. J. et al. First report of papaya fruit rot caused by Colletotrichum magna in Brazil. Plant Disease, v. 94 , n. 12, p. 1506, 2010.

NERY-SILVA, F. A. et al. Controle químico da podridão peduncular de mamão causada por Colletotrichum gloeosporioides. Ciência Agrotécnica, v. 25, n. 3, p. 519524, 2001.

RIBEIRO, J. G.; SERRA, I. M. R. S.; ARAÚJO, M. U. P. Uso de produtos naturais no controle de antracnose causada por Colletotrichum gloeosporioides em mamão. Summa Phytopathologica, v. 42, n. 2, p. 160-164, 2016.

RONCATO, M. C.; PASCHOLATI, S. F. Alterações na atividade e no perfil eletroforético da peroxidase em folhas de milho (Zea mays) e sorgo (Sorghum bicolor) tratadas com leveduras (Sccharomyces cerevisiae). Scientia Agricola, v. 55, n. 3, p. 395-402, 1998.

RUGGIERO, C.; MARIN, S. L. D.; DURIGAN, J. F. Mamão, uma história de sucesso. Revista Brasileira de Fruticultura, special vol., p. 76-82, 2011.

SHANER, G.; FINNEY, R. E. The effects of nitrogen fertilization on the expression of slow mild wing in knox wheat. Phytopathology, v. 67, n. 1, p. 1051-1055, 1977.

STANGARLIN, J. R. et al. A defesa vegetal contra fitopatógenos. Scientia Agraria Paranaensis, v. 10, n. 1, p. 18-46, 2011.

SUTTON, B. C. The genus Glomerella and its anamorph Colletotrichum. In: BAILEY, J. A.; JEGER, M. J. Colletotrichum: biology, pathology and control. Oxon: $\mathrm{CAB}$ International, 1992. p. 1-26.

UMESHA, S. Phenylalanine ammonia-lyase activity in tomato seedlings and its relationship to bacterial cancker diseases resistance. Phytoparasitica, v. 34, n. 1, p. 68-71, 2006.

VIANA, E. de S. et al. Avaliação físico-química e sensorial de frutos de genótipos melhorados de mamoeiro. Pesquisa Agropecuária Tropical, v. 45, n. 3, p. 297-303, 2015.

WILLS, R. B. H.; WIDJANARKO, S. B. Changes in physiology, composition and sensory characteristics of Australian papaya during ripening. Australian Journal of Experimental Agriculture, v. 8, n. 35, p. 1173-1176, 1995. 